\title{
Konseling Pendidikan Seks dalam Pencegahan Kekerasan Seksual Anak (KSA)
}

\author{
Ruwanti Wulandari ${ }^{1}$, Jaja Suteja ${ }^{2}$ \\ ${ }^{1}$ SMA Negeri 1 Astana Japura Cirebon \\ Email Penulis 1: wulandariwanti80@yahoo.co.id \\ ${ }^{2}$ Program Studi Bimbingan Konseling Islam, Fakultas Ushuluddin Adab Dakwah, \\ IAIN Syekh Nurjati Cirebon \\ Email Penulis 2: jaja.suteja@syekhnurjati.ac.id
}

\begin{abstract}
Abstrak
Kasus-kasus kekerasan seksual terhadap anak di Indonesia akhir-akhir ini semakin marak terjadi. Kekerasan seksual, tidak saja terjadi pada laki-laki namun juga pada anak perempuan. Pelaku dari kekerasan seksual dapat berasal dari orang lain yang tidak di kenal anak, namun juga terkadang justru dari keluarga dekat. Kasus kekerasan seksual di Kabupaten Cirebon sendiri setiap tahun mengalami peningkatan. Berdasar data Unit Perlindungan Perempuan dan Anak (PPA) Polres Cirebon, pada tahun 2015 setidaknya terjadi 49 kasus kekerasan terhadap anak. Jumlah itu meningkat dibanding 2014 yang tercatat 34 kasus. Dalam kebanyakan kasus tersebut, para pelaku mayoritas merupakan orang yang dikenal korban seperti tetangga, teman, hingga saudara korban.Dari masalah di atas, salah satu penyelesaiannya melalui kegiatan konseling pendidikan seks. Pendidikan seks pada anak dilaksanakan meliputi beberapa aspek antara lain : pertama, pengajaran yakni penjelasan tentang organ reproduksi laki-laki dan perempuan, kehamilan, ihtilam (mimpi basah), haid dan keputihan. Kedua, Penyadaran yakni menanamkan rasa malu pada anak, mendidik anak agar selalu menjaga pandangan mata, mendidik anak agar tidak melakukan ikhtilat dan khalwat, memilihkan tayangan televisi yang baik buat anak. Ketiga, penerangan yakni menjelaskan tentang IMS. Kesimpulan dari penelitian ini menghasilkan temuan bahwa pelaksanaan konseling pndidikan seks yang dilakukan oleh seorang konselor terhadap klien memiliki peranan yang sangat penting dalam prevensi kekerasan seksual anak. Kegiatan konseling pendidikan seks dilakukan tidak hanya sebagai upaya membantu mengatasi masalah klien yang berkaitan dengan seksualitasnya, melainkan berkaitan juga dengan upaya-upaya pendidikan dalam meningkatkan kesadaran akan masa depannya.
\end{abstract}

Kata Kunci: Konseling Pendidikan Seks; Prevensi; Kekerasan Seksual Anak. 


\section{PENDAHULUAN}

Beberapa tahun yang lalu dunia pendidikan di Indonesia dikejutkan oleh berita yang sangat menyedihkan dan menjadi perhatian semua pihak, yakni terjadinya kekerasan seksual yang menimpa murid TK/SD Jakarta International School (JIS). Pelaku kekerasan seksual terhadap anak tersebut dilakukan oleh seorang pendidik atau guru yang sehariharinya mengajar disana. Sementara itu, di Forth Worth, Texas, Amerika, pada tahun 2001 pernah terbongkar situs porno anak-anak yang dikelola oleh Thomas Reedy yang bekerja sama dengan orang Indonesia. Sebelumnya, penelitian yang dilakukan oleh Rohman dan Adria (1999) di Kuta dan Legian, Bali, juga menemukan bahwa sebagian anak jalanan di sana telah menjadi objek seksual para pedofil dari luar negeri. Anak-anak yang secara ekonomi dalam kondisi miskin biasanya dengan mudah menjadi korban bujuk rayu para pedofil yang menawarkan iming-iming materi berupa uang dan kemewahan. Pada awalnya, anak-anak itu umumnya tidak sadar bahwa dirinya telah menjadi korban pedofil yang berbahaya. Bahkan, kalaupun suatu ketika mereka sadar bahwa dirinya telah menjadi korban pedofilia, tidak sedikit dari mereka ujung-ujungnya hanya bersikap pasrah karena adanya ketergantungan yang dengan sengaja diciptakan oleh para pedofil untuk menjerat mangsanya (Suyanto, Jawa Pos, 19 April 2014).

Di Indonesia sendiri, kasus pedofilia sesungguhnya adalah salah satu dari tindak kekerasan terhadap anak yang semakin lama semakin mencemaskan. Meski secara statatistik anak-anak korban sodomi tidak sebanyak jumlah anak yang menjadi korban tindak kekerasan yang lain, ada indikasi persoalan ini adalah fenomena "gunung es". Bisa dibayangkan, bagaimana hati para orang tua yang selama ini mempercayakan pendidikan anak-anaknya di sekolah dan di bawah bimbingan guru yang profesional ketika di sana ternyata justru marabahaya tengah mengancam anak-anaknya. Sebab, dengan terjadinya kekerasan seksual yang menimpa salah seorang siswa TK/SD JIS tidak tertutup kemungkinan terjadi juga di beberapa sekolah dasar yang ada di Indonesia.

Komisi Perlindungan Anak Indonesia (KPAI) menyatakan, kekerasan seksual paling banyak terjadi di lingkungan sekolah. Guru di sekolah dasar dan sekolah menegah pertama menjadi pelaku terbanyak. Bahkan sepanjang tahun 2018, KPAI juga menemukan kasus yang tidak biasa. Karena korban kekerasan seksual tidak hanya dialami siswa perempuan melainkan juga murid laki-laki. KPAI mencatat selama tahun 2018, ada 177 korban kekerasan seksual. Sebanyak 135 korban diantaranya merupakan korban laki-laki dan 42 orang lainnya adalah korban perempuan. Sebagai salah satu kasus kekerasan seksual anak yang dilakukan oleh seorang guru kepada siswanya, sebagaimana yang dilakukan oleh oknum guru olah raga yang berinisial AK di salah satu SMP Negeri di Pekayon Jakarta Timur yang melakukan pelecehan seksual kepada tiga orang muridnya. Modus yang dilakukan oleh AK yakni dengan mengiming-imingi korban untuk melakukan aksinya (https://m.cnnindonesia.com>nasional diakses tanggal 30 maret 2019).

Kasus lainnya juga dilakukan oleh seorang oknum guru agama Sekolah Dasar di Kecamatan Kalukku Mamuju Sulawesi Barat yang melakukan pelecehan seksual terhadap 15 orang siswanya. Modus yang dilakukan oleh pelaku yakni pemaksaan dan 
pengancaman dengan cara memegang kemaluan siswi di ruangan kelas. Bahkan kasus pelecehan seksual yang dilakukan oleh oknum guru agama tersebut berlangsung beberapa tahun kepada siswi kelas empat, kelas lima dan kelas enam Sekolah Dasar (https://regional.kompas.com.2019 diakses tanggal 30 maret 2019). Hal ini menunjukkan bahwa saat ini belum ada dunia yang aman untuk anak-anak, semakin lama semakin sulit untuk ditemukan. Sekolah dan keluarga yang seharusnya menjadi tempat yang aman dan nyaman bagi anak justru seringkali menjadi tempat yang mengerikan bagi anak. Bahkan seringkali banyak korban kekerasan seksual yang tidak tahu bagaimana harus menyikapi kekerasan yang dirasakan dan dialaminya. Hal ini merupakan salah satu tanda minimnya pengetahuan anak berkaitan dengan pendidikan seksual (detik.com, 2018).

Maraknya kasus kekerasan seksual yang terjadi belakangan ini tidak lagi hanya mengancam anak-anak yang kurang memahami terhadap informasi yang salah mengenai seks. Meningkatnya kasus kekerasan merupakan bukti nyata kurangnya pengetahuan anak mengenai pendidikan seks yang seharusnya sudah mereka peroleh sejak memasuki Sekolah Dasar. Pendidikan seks menjadi penting mengingat banyaknya kasus-kasus yang terjadi mengenai tindak kekerasan seksual terhadap anak. Hasil penelitian yang dikutip dari sebuah Jurnal Pemikiran Alternatif Pendidikan mengenai Pendidikan Seks pada Usia Dini oleh Moh. Roqib menunjukkan, bahwa 97,05\% mahasiswa di Yogyakarta telah kehilangan keperawanannya. Nyaris $100 \%$ atau secara matematis bisa disepadankan dengan 10 gadis dari 11 gadis sudah tidak perawan yang diakibatkan oleh hubungan seksual. Fakta yang sangat memprihatinkan melihat kondisi remaja saat ini yang tengah terancam dalam mempertahankan kesucian dirinya baik karena paksaan atau karena samasama suka saat melakukannya (free sex). Hal ini menunjukkan bahwa perlunya pendidikan seks untuk diberikan sejak anak-anak dalam rangka memberikan informasi dan mengenalkan kepada anak bagaimana ia harus menjaga dan melindungi organ tubuhnya dari orang yang berniat jahat terhadap dirinya.

Kekerasan seksual pada anak (child abuse) merupakan suatu tindakan perilaku yang dilakukan seseorang terhadap individu lain yang dapat mengakibatkan gangguan secara fisik dan psikis. Kekerasan seksual yang dialami dan dirasakan seorang anak tidak saja mengakibatkan gangguan fisik dan mental, juga mengakibatkan gangguan secara sosial dan merusak masa depan pendidikan anak. Karena itu, kekerasan seksual yang berdampak psikologis biasanya menimbulkan trauma bahkan menyebabkan depresi kepada anak. Sedangkan kekerasan seksual yang berdampak sosial, seringkali menyebabkan anak dipaksa untuk menjadi pelacur, pembantu, atau bahkan pengamen jalanan. Selain berdampak secara psikologis dan sosial, korban kekerasan seksual juga seringkali menjadikan anak tidak memiliki semangat untuk melanjutkan pendidikan ke jenjang yang lebih tinggi karena merasa malu terhadap orang-orang yang ada di sekitarnya.

Kejadian kekerasan seksual yang menimpa siswa SD di atas seharusnya semakin memberi kesadaran semua pihak bahwa sudah tiba waktunya mengubah anggapan tentang tabunya pendidikan seksual diberikan kepada siswa Sekolah Dasar. Pendidikan seksual untuk anak bukan mengajarkan anak untuk melakukan seks bebas ketika mereka dewasa 
kelak. Melainkan pendidikan seksual tersebut dimaksudkan agar anak memahami akan kondisi tubuhnya, kondisi tubuh lawan jenisnya, serta menjaga dan menghindarkan anak dari kekerasan seksual. Cakupan pendidikan seksualitas meliputi perkembangan seksual, penciptaan manusia, perbedaan anatomi seksual laki-laki dan perempuan, hasrat seksual, orientasi seksual, hubungan seksual, masturbasi, aborsi, alat kontrasepsi, perzinahan, khitan dan kekerasan seksual (Qibtiyah, 2006). Namun demikian, dalam penelitian ini peneliti akan memfokuskan pada kasus kekerasan seksual anak. Karena angka kekerasan seksual anak di Indonesia setiap tahun mengalami peningkatan.

Sedangkan sex education atau pendidikan seks merupakan pendidikan mengenai kesehatan alat reproduksi. Pendidikan seks sama dengan penerangan tentang anatomi fisiologis seks manusia, tentang bahaya-bahaya penyakit kelamin dan sebagainya. Pendidikan seks sendiri dimaksudkan agar seseorang dapat memahami arti, fungsi dan tujuan seks, sehingga pada waktunya nanti bisa menyalurkan kebutuhan seks secara benar. Pendidikan seks adalah bagian dari komponen pokok kehidupan yang dibutuhkan manusia, karena pada dasarnya mengkaji pendidikan seks pada hakekatnya adalah mengkaji kebutuhan hidup (Rosyid, 2008, hlm. 83).

Dalam pendidikan seks dapat dibedakan antara sex instruction dan education in sexuality.Sex instruction ialah penerangan mengenai anatomi dan psikologi seksual, seperti pertumbuhan bulu pada ketiak dan sekitar alat kelamin, dan mengenai proses reproduksi untuk mempertahankan jenis. Termasuk di sini pembinaan keluarga dan alat-alat kontrasepsi dalam mencegah terjadinya kehamilan. Sedangkan education in sexuality meliputi bidang-bidang etika, moral, fisiologi, ekonomi dan pengetahuan lainnya yang dibutuhkan seseorang dapat memahami diri sendiri sebagai individu seksual serta mengadakan hubungan interpersonal yang baik (Miqdad, 1997, hlm. 9).

\section{PEMBAHASAN}

\section{Konsep Pendidikan Seks dalam Tinjauan Islam}

Islam adalah agama yang sangat memperhatikan kebahagiaan individu dan keluarga serta masyarakat. Memasuki jenjang rumah tangga, selain didukung kematangan seksual (well-adjusted) perlu didukung pula oleh moral agama, sehingga dapat melaksanakan seksualitasnya secara bertanggung jawab bagi dirinya masing- masing serta lingkungan sosialnya sesuai dengan agama. Karena dalam agama telah diatur peranan seks dalam perkawinan dalam kehidupan sehari-hari. Agama dapat menjamin kebahagiaan dalam kehidupan suami-isteri, hanya kata ini bukan dari para ulama, melainkan merupakan pernyataan yang didukung oleh fakta-fakta, keruntuhan moral di bidang seks, baik bagi anak-anak, remaja muda maupun bagi pasangan-pasangan suami-istri adalah karena kebanyakan mengesampingkan tuntunan agama, hingga tidak memiliki keyakinan iman sebagai pegangan hidup (Gunawan, 2010, hlm. 53).

Dalam lingkup Pendidikan Islam, Pendidikan seks merupakan bagian dari pendidikan akhlak dan pendidikan akhlak merupakan bagian dari pendidikan agama Islam. (Akbar, 1982, hlm. 17). Maka dengan demikian dasar pendidikan seks sama dengan dasar 
pendidikan agama Islam, yaitu Al-Qur'an dan Hadits. Dan yang menjadi dasar dan petunjuk pelaksanaan pendidikan seks dalam Al-Qur'an adalah sebagai berikut:

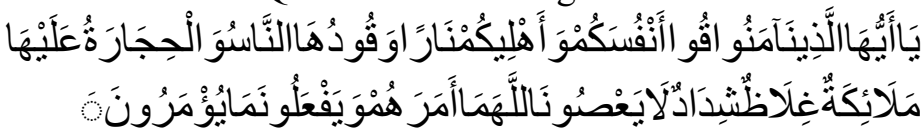

Artinya:

Hai orang-orang yang beriman, peliharalah dirimu dan keluargamu dari api neraka yang bahan bakarnya adalah manusia dan batu; penjaganya malaikat-malaikat yang kasar, keras, dan tidak mendurhakai Allah terhadap apa yang diperintahkan-Nya kepada mereka dan selalu mengerjakan apa yang diperintahkan. (Departemen Agama Republik Indonesia, 2005:561)

Pada ayat tersebut di atas memberi gambaran pada kita bahwa seorang mukmin harus bisa menjaga diri kita juga keluarga kita dari berbuat dosa yang mengakibatkan masuk neraka. Jadi bukan hanya menjaga diri sendiri, namun kepala rumah tangga harus memberikan pengarahan yang baik dan menjauhkan keluarganya yaitu istri dan anak-anak mereka dari siksaan api neraka. Tentunya kalau untuk anak, pengarahan yang diberikan yaitu berupa pendidikan seks sesuai dengan usia anak mereka. Diberikan penjelasan batasan-batasan yang atau hal-hal yang tidak boleh dilakukan.

Al-Qur'an memberikan petunjuk yang jelas bahwa Islam memberikan perhatian yang serius terhadap pendidikan anak-anak sejak mengenal rasa malu tentang perilaku sosial dan etika Islam yang luhur sehingga ketika anak mencapai usia remaja, ia bisa menjadi sosok manusia yang dinamis dalam membentuk akhlak mulia dan amal yang terpuji (Ulwan dan Hassan Hathout, 1996, hlm. 4).

Sedangkan dasar pendidikan seks dalam hadits adalah sebagai berikut yang artinya:

"Dari Abi Hurairah r.a berkata: ketika Rasulullah SAW ditanya: apakah yang banyak memasukan orang kedalam surga? Beliau menjawab: "takwa kepada Allah dan akhlak yang baik". Dan ditanya apakah yang banyak memasukan orang ke dalam neraka? Beliau menjawab: "mulut dan faraj." (Diriwayatkan oleh Tirmidzi dan Hadis ini Hasan dan Sohih)

Menurut Abdullah Nashih Ulwan, beliau mengatakan bahwa ajaran Islam telah mengajarkan pendidikan seks sejak seseorang dilahirkan ke muka bumi hingga ia meninggalkan dunia fana ini. Menurut pendapatnya, Islam mengatur tentang cara pergaulan antara laki-laki dan perempuan dengan tuntutan dan pendidikan seks yang penuh kebijaksanaan. Sehingga setiap muslim akan terpelihara dari perbuatan yang menimbulkan pelanggaran dan penyimpangan seks yang tidak diinginkan oleh orang tua maupun masyarakat (Ulwan, 2015, hlm. 424). 
Menurut pandangannya, bahwa pada prinsipnya dalam Islam pendidikan seks bertujuan agar manusia mampu menyalurkan fitrah manusianya untuk menciptakan keluarga sakinah, mawaddah, dan rahmah. Bagitu pentingnya masalah seksual, sehingga Islam benar-benar mengatur masalah seksual ini dari mulai masa kanak-kanak, remaja hingga dewasa yang kesemuanya ini merupakan dalam upaya menjaga dan melindungi kesucian seksual (Ulwan, 2015, hlm. 425). Ajaran Islam banyak mengajarkan aturanaturan yang berkenaan dengan masalah seksual ini di antaranya yaitu larangan hidup membujang, menjaga pandangan mata terhadap lawan jenis yang bukan muhrimnya, perlunya para wanita menutup aurat, larangan kawin dengan saudara sekandung, larangan berzina, dan sebagainya. Semua hal tersebut, merupakan pedoman pendidikan seks yang telah dinyatakan dalam al-Qur'an dan Hadits Nabi Muhammad SAW. Adanya pedoman pendidikan seks tersebut, sebagai konsekuensi logis dari pengakuan Islam terhadap naluri seksual dan sebagai bukti, bahwa Islam menjunjung tinggi kesucian dan keluhuran dorongan-dorongan seksual pada manusia (Ulwan, 2015, hlm. 426).

Umat Islam diperintahkan agar mempunyai kemampuan untuk menganalisa dalam masalah seks, yaitu dengan cara memilih antara informasi seks yang baik dan tidak baik, sehingga dapat mengetahui informasi yang pantas untuk dilaksanakan dan mana yang harus ditinggalkan atau dibuang jauh-jauh (Widjanarko, 1994, hlm. 202 -204). Menurut Ulwan dan Hasan Hathout (1986, hlm. 29-32) menjelaskan bahwa di antara nilai-nilai pendidikan seks yang dapat diberikan oleh orang tua kepada anak-anak remajanya antara lain meliputi:

1. Membiasakan anak tidur terpisah dengan orang tua.

2. Mengajarkan etika meminta izin untuk masuk kamar.

3. Mendidik anak dan remaja agar menutup aurat dan berpakaian Islami.

4. Mendidik remaja agar menundukkan pandangan dan menjaga pandangan mata.

5. Mendidik remaja agar tidak berduaan dengan lawan jenis.

6. Mendidik agar menahan diri bila tidak mampu menikah.

Dalam ajaran Islam sendiri, yang memiliki tanggung jawab terhadap perkembangan seksual seorang anak adalah kedua orang tuanya atau keluarganya. Menurut Nina Surtiretna dalam Zakiyah Darajat (2000, hlm. 8) menyatakan bahwa pendidikan seks dalam keluarga merupakan alternatif dalam membekali anak-anaknya mengenai informasi seks yang benar. Jadi orang tua harus membangun suasana keakraban, keterbukaan, dan komunikasi yang harmonis kepada anak-anaknya terutama membicarakan mengenai permasalahan-permasalahan seksual. Islam mengajarkan kepada orang tua, agar berterus terang kepada anak-anaknya baik laki-laki maupun perempuan tentang pendidikan seks menurut ilmu psikologi pendidikan maupun menurut ilmu keislaman. Hal ini seperti yang telah disampaikan tentang hukum memandang dan etika meminta izin. 


\section{Kekerasan Seksual Terhadap Anak}

\section{Pengertian Kekerasan}

Kekerasan secara umum bisa diartikan dengan penganiayaan, penyiksaan, atau perlakuan salah. Istilah tindak kekerasan pada anak ini dalam dunia barat terkenal dengan istilah child abuse dan neglect, istilah ini awalnya berkembang dan dikenal dalam dunia kedokteran. WHO (dalam Bagong. S, dkk, 2000) mengartikan kekerasan dengan maksud penggunaan kekuatan fisik dan kekuasaan, ancaman atau tindakan terhadap diri sendiri, perorangan atau sekelompok orang atau masyarakat yang mengakibatkan atau kemungkinan besar mengakibatkan memar/trauma, kematian, kerugian psikologis, kelainan perkembangan atau perampasan hak.

Caffey-seorang radiologist kurang lebih pada tahun 1946 melaporkan adanya kasus yang terjadi dalam dunia kedokteran berupa cedera yang wujudnya adalah beberapa gejala klinik yang diantaranya adalah kasus patah tulang panjang yang majemuk (multiple fractures) pada anak-anak atau bayi disertai pendarahan subdural tanpa mengetahui sebabnya (unrecognized trauma). Istilah ini kemudian dikenal dengan sebutan Caffey Syndrome dalam dunia kedokteran (Ranuh, 1999).

Lebih lanjut istilah Child Abuse ini dijelaskan oleh Barker (dalam Huraerah, 2007) yaitu berupa tindakan melukai beulang-ulang secara fisik dan emosional terhadap anak yang ketergantungan, melalui desakan hasrat, hukuman badan yang tak terkendali, degradasi dan cemoohan permanen atau kekerasan seksual. Sedangkan kekerasan seksual sendiri ditujukan pada penyebutan istilah bagi bentuk kontak seksual yang sebenarnya tidak diinginkan secara seksual. Dalam kasus kekerasan seksual kebanyakan dibarengi dengan adanya tekanan psikologis atau fisik (O'Barnett et al., dalam Matlin, 2008). Kasus kekerasan seksual yang spesifik biasanya dikenal dengan istilah perkosaan. Perkosaan ini diilustrasikan sebagai penetrasi seksual tanpa izin atau dengan paksaan, disertai oleh kekerasan fisik (Tobach, dkk. dalam Matlin, 2008).

\section{Bentuk-bentuk Kekerasan Seksual terhadap Anak}

Bentuk-bentuk kekerasan seksual terhadap anak bisa ditinjau dari 3 sudut pandang. Pertama adalah dari sudut pandang penderita, yaitu si anak dan pelaku serta wujud perlakuannya. Kedua adalah dari sudut pandang hubungan pelaku dan penderita, dan yang ketiga adalah pengelompokan berdasarkan bentuk-bentuk perlakuannya.

Pertama ditinjau dari sudut pandang penderita, yaitu si anak dan pelaku serta wujud perlakuannya, seorang psikiater internasional Terry E. Lawson (dalam Huraerah, 2007) menulis definisi tentang child abuse, dengan mengkategorikan bahwa ada empat bentuk abuse, yaitu emotional abuse, verbal abuse, physical abuse, dan sexual abuse.

a. Physical abuse, atau dikenal dengan istilah kekerasan secara fisik. Kekerasan ini terjadi saat orang tua atau pengasuh anak melakukan pemukulan terhadap si anak pada saat anak sbetulnya sedang memerlukan perhatian. Menurut pakar ini pukulan yang diberikan akan diingat anak itu jika kekerasan fisik itu berlangsung dalam periode tertentu. Kekerasan ini berwujud melukai bagian tubuh anak. 
b. Emotional abuse atau yang diartikean dalam bahasa Indonesia sebagai kekerasan emosional. Model kekerasan ini terjadi saat orang tua atau pengasuh anak sebenarnya telah mengetahui bahwa anaknya meminta perhatian namun ia ternayta mengabaikan si anak. Bentuknya misalnya anak basah atau lapar tapi diabaikan karena terlalu sibuk. Selanjutnya anak akan mengingat semua kekerasan emosional jika hal ini berlangsung konsisten.

c. Verbal abuse, yaitu dalam bahasa Indonseia diartikan dengan istilah Kekerasan Verbal. Kekerasan ini umumnya berupa perilaku verbal, yaitu berupa penghinaan, melecehkan anak, menyalahkan, melabeli, mengkambinghitamkan, dan sebagainya.

d. Sexual abuse, yaitu yang biasa dikenal dalam bahasa Indonesia berupa Kekerasan Seksual. Kekerasan jenis ini berupa pemaksaan hubungan seksual yang dilakukan terhadap orang yang menetap masih dalam cakupan rumah tangga yang bersangkutan mulai dari istri, anak dan pekerja atau pembantu rumah tangga. Sexual Abuse dalam perkembangan selanjutnya dipahami sebagai semua tindakan yang berupa pemaksaan hubungan seksual, atau juga berwujud pemaksaan hubungan seksual dengan cara tidak wajar dan atau tidak disukai baik bertujuan komersil dan atau tujuan tertentu.

Kedua, ditinjau dari Hubungan pelaku dan korban, yaitu dibagi berdasrkan identitas pelaku (Tower, 2002):

a. Familial Abuse Incest, ini diartikan sebagai sexual abuse yang terjadi dalam ruanglingkup masih punya hubungan darah. Pelaku dan korban termasuk dalam keluarga inti. Hal ini menurut Mayer dibagi dalam 3 kategori.

1) Kategori pertama adalah sexual molestation, ini yang diartikan sebagai penganiayaan yang meliputi interaksi non-coitus, petting, fondling, exhibitionism, dan voyeurism, yaitu semua perlakuan yang berkaitan untuk menstimulasi pelaku secara seksual.

2) Kategori kedua adalah sexual assault atau yang dikenal dengan istilah perkosaan dalam bahasa Indonesia. Ini berupa oral atau hubungan dengan alat kelamin, masturbasi, fellatio (stimulasi oral pada penis), dan cunnilingus (stimulasi oral pada klitoris).

3) Kategori ke 3 yaitu yang didefinisakn sebagai perlakuan yang paling fatal yang dikenal dengan istilah forciblerape, yaitu berupa perkosaan secara paksa. Menurut Mayer dua kategori terakhirlah yang menimbulkan trauma terberat bagi anak-anak.

b. Extrafamilial Abuse, yaitu kekerasan seksual dilakukan oleh orang lain di luar keluarga korban. Masih menurut Mayer ini kurang lebih hanya $40 \%$ yang berani melaporkan kekerasan seksual ini. Pelakunya biasanya disebut pedophile karena korban utamanya adalah anak-anak. Pedophilia diartikan "menyukai anak-anak" (deYong dalam Tower, 2002). 
Pornografi anak menggunakan anak-anak sebagai sarana untuk menghasilkan gambar, foto, slide, majalah, dan buku (O’Brien, Trivelpiece, Pecora et al., dalam Tower, 2002). Biasanya ada tahapan yang terlihat dalam melakukan kekerasan seksual Kemungkinan pelaku mencoba perilaku untuk mengukur kenyamanan korban. Jika korban menuruti, kekerasan akan berlanjut dan intensif, berupa:

1) Nudity (dilakukan oleh orang dewasa).

2) Disrobing (orang dewasa membuka pakaian di depan anak).

3) Genitalexposure (dilakukan oleh orang dewasa).

4) Observationofthechild (saat mandi, telanjang, dan saat membuang air).

5) Mencium anak yang memakai pakaian dalam.

6) Fondling (meraba-raba dada korban, alat genital, paha, dan bokong).

7) Masturbasi.

8) Fellatio (stimulasi pada penis, korban atau pelaku sendiri).

9) Cunnilingus (stimulasi pada vulva atau area vagina, pada korban atau pelaku).

10) Digitalpenetration (pada anus atau rectum).

11) Penilepenetration (pada vagina).

12) Digitalpenetration (pada vagina).

13) Penilepenetration (pada anus atau rectum).

14) Dryintercourse (mengelus-elus penis pelaku atau area genital lainnya, paha, atau bokong korban) (Sgroi dalam Tower, 2002).

Pengelompokan bentuk-bentuk kekerasan seksual yang ke 3 yaitu menurut Suharto (1997), dibagi menjadi:

a. Kekerasan seksual anak Secara Fisik. Kekerasan secara fisik adalah penyiksaan, pemukulan, dan penganiayaan terhadap anak, dengan atau tanpa menggunakan benda-benda tertentu, yang menimbulkan luka-luka fisik atau kematian pada anak. Bentuk luka dapat berupa lecet atau memar akibat persentuhan atau kekerasan benda tumpul, seperti bekas gigitan, cubitan, ikan pinggang, atau rotan. Dapat pula berupa luka bakar akibat bensin panas atau berpola akibat sundutan rokok atau setrika. Lokasi luka biasanya ditemukan pada daerah paha, lengan, mulut, pipi, dada, perut, punggung atau daerah bokong.

b. Kekerasan Anak Secara yaitu Psikis. Kekerasan seksual secara psikis dapat dilakukan dengan cara penyampaian kata-kata kotor yang berkaitan dengan seks, memperlihatkan buku, gambar, dan film pornografi pada anak. Anak yang mendapatkan perlakuan ini umumnya menunjukkan gejala perilaku maladaptif, seperti menarik diri, pemalu, menangis jika didekati, takut ke luar rumah dan takut bertemu dengan orang lain.

c. Kekerasan Anak Secara seksual yaitu yang berupa perlakuan prakontak seksual antara anak dengan orang yang lebih besar (melalui kata, sentuhan, gambar visual, 
exhibisionism), maupun perlakuan kontak seksual secara langsung antara anak dengan orang dewasa (incest, perkosaan, eksploitasi seksual).

d. Kekerasan Anak Secara Sosial. Kekerasan secara sosial dapat mencakup penelantaran anak dan eksploitasi seksual anak. Penelantaran anak adalah sikap dan perlakuan orangtua yang tidak memberikan perhatian yang layak terhadap proses tumbuh-kembang anak. Misalnya anak dikucilkan, diasingkan dari keluarga, atau tidak diberikan pendidikan dan perawatan kesehatan yang layak. Eksploitasi seksual anak menunjuk pada sikap diskriminatif atau perlakuan sewenang-wenang terhadap anak yang dilakukan keluarga atau masyarakat.

\section{Faktor Penyebab Kekerasan Seksual terhadap Anak}

Faktor Penyebab Kekerasan seksual terhadap Anak ini menurutGelles Richard.J (1982) terjadi karena sebagai bentuk kombinasi dari berbagai faktor, yaitu:

a. Intergenerational transmission of violance, yaitu yang dikenal dalam pengertian bahasa Indonesia berupa Pewarisan Kekerasan Antar Generasi. Ini diartikan bahwa perilaku kekerasan anak kebanyakan dari orangtuanya dan ketika tumbuh menjadi dewasa. Orang tua melakuakan tindakan kekerasan kepada anaknya saat masa pertumbuhan si anak lau perilaku kekerasan diwarisi.

b. Social stress, yaitu yang dipahami sebagai stres sosial yang ditimbulkan oleh berbagai kondisi sosial meningkatkan risiko kekerasan terhadap anak dalam keluarga. Beberapa kondisi ini yaitu pengangguran (unemployment), penyakit (illness), kondisi perumahan buruk (poor housing conditions), ukuran keluarga besar dari rata-rata (a larger than average family size), kelahiran bayi baru (the presence of a new baby), orang cacat (disabled person) di rumah, dan kematian (the death) seorang anggota keluarga.

c. Social isolation yaitu isolasi sosial.Ini dipahami sebagai orangtua atau orang tua asuh yang melakukan tindakan kekerasan terhadap anak cenderung terisolasi secara sosial.

d. Family structure atau struktur keluarga yaitu yang dipahami bahwa tipe-tipe keluarga tertentu memiliki risiko melakukan tindakan kekerasan dan pengabaian kepada anak. Misalnya, orangtua tunggal lebih memungkinkan melakukan tindakan kekerasan terhadap anak dibandingkan dengan orangtua utuh. Selain itu, keluargakeluarga di mana baik suami atau istri mendominasi di dalam membuat keputusan penting, seperti: di mana bertempat tinggal, dan sebagainya.

\section{Efek Kekerasan Seksual}

Menurut Beitch-man et al. (dalam Tower, 2002), Semua kekerasan seksual yang dialami anak yang disebutkan di atas otomatis akan berdampak pada anak. Korban kekerasan seksual seperti misalnya perkosaan akan merasakan kriteria psychological disorder yang disebut post-traumatic stress disorder (PTSD), simtom-simtomnya berupa ketakutan yang intens terjadi, kecemasan yang tinggi, emosi yang kaku setelah peristiwa traumatis. Efeknya korban yang mengalami kekerasan ini minimal membutuhkan waktu satu hingga tiga tahun untuk terbuka pada orang lain. Sementara 
itu Finkelhor dan Browne (dalam Tower, 2002) menyampaikan bahwa ada empat jenis dari efek trauma akibat kekerasan seksual, yaitu:

a. Betrayal (penghianatan) kepercayaan merupakan dasar utama bagi korban kekerasan seksual. Sebagai anak individu percaya kepada orangtua dan kepercayaan itu dimengerti dan dipahami. Namun, kepercayaan anak dan otoritas orangtua menjadi hal yang mengancam anak.

b. Traumatic sexualization (trauma secara seksual) Russel (dalam Tower, 2002) menemukan bahwa perempuan yang mengalami kekerasan seksual cenderung menolak hubungan seksual, dan sebagai konsekuensinya menjadi korban kekerasan seksual dalam rumah tangga. Finkelhor (dalam Tower, 2002) mencatat bahwa korban lebih memilih pasangan sesama jenis karena menganggap laki-laki tidak dapat dipercaya.

c. Powerlessness atau merasa tidak berdaya.Akibat efek ini, kehidupan korban dipenuhi rasa takut, mimpi buruk, fobia, dan kecemasan. Korban mempunya perasaan tidak berdaya mengakibatkan individu merasa lemah (Finkelhor dan Browne, Briere dalam Tower, 2002).

d. Stigmatization, yaitu berupa perasaan korban kekerasan seksual yang merasa bersalah, malu, memiliki gambaran diri yang buruk. Wujudnya beberapa korban marah pada tubuhnya akibat penganiayaan yang dialami. Korban lainnya menggunakan obat-obatan dan minuman alkohol untuk menghukum tubuhnya, menumpulkan inderanya, atau berusaha menghindari memori kejadian tersebut (Gelinas, Kinzl dan Biebl dalam Tower, 2002).

\section{Metode dan Konseling Pendidikan Seks dalam Pencegahan Kekerasan Seksual Anak}

\section{Pengertian Konseling}

Konseling merupakan sistem dan proses bantuan untuk mengentaskan masalah yang terbangun dalam suatu hubungan tatap muka antara dua orang individu (klien yang menghadapi masalah dengan konselor yang memiliki kualifikasi yang dipersyaratkan).Konseling (penyuluhan) adalah hubungan tatap muka antara konselor dan klien dalam rangka membantu klien untuk mencapai tujuan-tujuan di atas. Dalam hal ini, konseling merupakan inti kegiatan dan salah satu teknik utama dalam bimbingan. Dengan demikian, dapat dikatakan bahwa semua konseling merupakan kegiatan bimbingan, tetapi tidak semua kegiatan bimbingan termasuk ke dalam konseling.

Konseling merupakan bentuk layanan yang paling utama dalam pelaksanaan fungsi pengentasan masalah klien. Dengan demikian konseling perorangan merupakan "jantung hati". Implikasi lain pengertian "jantung hati" adalah apabila seorang konselor telah menguasai dengan baik apa, mengapa dan bagaimana pelayanan konseling itu (memahami, menghayati dan menerapkan wawasan, pengetahuan dan ketrampilan dengan berbagai teknik dan teknologinya), maka diharapkan ia dapat 
menyelenggarakan layanan-layanan bimbingan lainnya tanpa mengalami banyak kesulitan.

Konseling sebagai sebuah proses pemberian bantuan kepada individu dilaksanakan melalui berbagai macam layanan. Tujuannya adalah tetap memberikan konseling dengan cara-cara yang lebih menarik, interaktif, dan tidak terbatas oleh tempat, tetapi juga tetap memperhatikan asas-asas dan kode etik dalam bimbingan dan konseling. Konseling mengandung makna proses antar pribadi yang berlangsung melalui saluran komunikasi verbal dan non-verbal. Konseling berbeda dengan bimbingan, namun memiliki tingkat kesesuaian yang tercakup dalam bimbingan konseling.

Bimbingan adalah relasi yang bertujuan menolong individu dari ketidakpahaman dan ketidaktahuannya dalam menghadapi sebuah permasalahan. Sedangkan konseling bertujuan menyelesaikan permasalahan setuntas-tuntasnya, agar individu mendapatkan informasi dan orientasi dari langkah yang akan dilakukan dalam menghadapi permasalahannya baik itu masalah pribadi, sosial, pekerjaan, pendidikan, karier, dan masih banyak lagi lainnya. Kesamaannya terletak pada tujuan untuk semakin mengembangkan individu tersebut dalam setiap aspek-aspek kehidupannya.

Sedangkan konselor adalah seorang yang mempunyai keahlian dalam bidangnya seperti membimbing dan mengkonseling orang, seorang konselor harus melakukan bimbingan dan konseling dengan adanya kesepakatan dengan klien yang akan di bantu untuk menyelsaikan permasalahannya. Konseling juga dilakukan dengan kerahasiaan atau tidak boleh diketahui oleh orang lain, dalam melakukan konseling juga seorang konselor harus mempunyai strategi-strategi yang tepat untuk menyelesaikannya.

Peran utama konselor dalam melakukan konseling terhadap klien korban kekerasan seksual adalah sebagai "Pengingat" yaitu sebagai orang yang mengingatkan indivdidu yang dibimbing dengan cara Allah. Dikatakan mengingatkan sebab (a) pada dasarnya individu telah memiliki iman, jika iman yang ada pada individu tidak tumbuh diduga individu lupa merawatnya, lupa memberi pupuknya, atau diserang penyakit; akibatnya iman itu tidak tumbuh dan tidak berfungsi dengan baik. (b) Allah telah mengutus rasul-Nya dengan membawa Kitab Suci sebagai pedoman hidup, jika ada individu yang mengalami kebingungan atau salah jalan diduga mereka belum memahami petunjuk itu. Oleh karena itu bagi mu'min yang memiliki keahlian (konselor) berkewajiban untuk mengingatkannya.

Ada beberapa teknik dalam konseling, yang dapat dilakukan oleh seorang konselor dalam membantu klien korban kekerasan seksual yakni:

1) Attending (Perhatian). Attending adalah keterampilan/teknik yang digunakan konselor untuk memusatkanperhatian kepada klien korban KSA agar klien merasa dihargai dan terbina suasana yang kondusifsehingga klien bebas mengekspresikan/mengungkapkan pikiran , perasaan ataupun tingkahlakunya.

2) Opening (Pembukaan). Opening adalah ketrampilan/teknik untuk membuka/memulai komunikasi /hubungan konseling terhadap klien korban KSA. 
3) Acceptance. Acceptance adalah teknik yang digunakan konselor untuk menunjukan minat danpemahaman terhadap hal-hal yang dikemukakan klien korban KSA.

4) Restatement (Pengulangan). Restatement adalah teknik yang digunakan konselor untuk mengulangi/menyatakankembali pernyataan klien korban KSA.

5) Reflection Of Feeling (Pemantulan perasaan). Reflection of feeling (pemantulan perasaan) adalah teknik yang digunakan konseloruntuk memantulkan perasaan/sikap yang terkandung di balik pernyataan klien korban KSA.

6) Clarification. Clarification adalah teknik yang digunakan untuk mengungkapkan kembali isipernyataan klien korban KSA dengan menggunakan kata-kata baru dan segar.

7) Paraprashing. Paraprashing adalah kata-kata konselor untuk menyatakan kembali esensi dariucapan-ucapan klien korban KSA.

8) Structuring (Pembatasan). Structuring adalah teknik yang digunakan konselor untuk memberikan batas-batas/pembatasan agar proses konseling berjalan sesuai dengan apa yang menjadi tujuan dalamkonseling.

9) Lead (Pengarahan). Lead adalah teknik/ketrampilan yang digunakan konselor untuk mengarahkanpembicaraan klien dari satu hal ke hal yang lain secara langsung. Ketrampilan ini sering puladisebut ketrampilan bertanya, karena dalam penggunaannya banyak menggunakan kalimat-kalimat tanya.

10) Silence (Diam). Silent/ Diam atau membiarkan keheningan berlangsung beberapa saat yang diciptakan secara sengaja dengan sejumlah tujuan tertentu yang disadari konselor.

11) Advice (Saran/nasehat). Advice adalah ketrapilan / teknik yang digunakan konselor untuk memberikan nasehatatau saran bagi klien agar dia dapat lebih jelas, pasti mengenai apa yang akan dikerjakan.

12) Summary (Ringkasan/kesimpulan). Summary adalah keterampilan/teknik yang digunakan konselor untuk menyimpulkanatau ringkasan mengenai apa yang telah dikemukakan klien korban KSA pada proses komunikasi konseling.

13) Konfrontasi (Pertentangan). Konfrontasi adalah ketrampilan/teknik yang digunakan oleh konselor untukmenunjukan adanya kesenjangan, diskrepansi atau inkronguensi dalam diri klien dankemudian konselor mengumpan balikan kepada klien korban KSA.

14) Interpretasi (Penafsiran). Interpretasi adalah ketrampilan/teknik yang digunakan oleh konselor dimana berartiatau karena tingkah laku klien ditafsirkan/diduga dan dimengerti dengan dikomunikasikanpada klien. Selain itu dalam interpretasi konselor menggali arti dan makna yang terdapat dibelakang kata - kata klien atau dibelakang perbuatan/tindakannya yang telah diceritakannya.

15) Termination (Pengakhiran). Termination adalah keterampilan/teknik yang digunakan konselor untuk mengakhirikomunikasi konseling, baik mengakhiri 
untuk dilanjutkan pada pertemuan berikutnya maupun mengakhiri karena komunikasi konseling betul-betul telah "berakhir".

\section{Metode Konseling Pendidikan Seks}

Dalam bahasa, seks memilik arti jenis kelamin. Namun setelah mengalami pergeseran makna, kata seks sering dianggap hubungan intim. Ini adalah salah satu faktor yang dapat mengakibatkan pendidikan seks menjadi sesuatu yang tabu. Banyak orang menganggap bahwa pendidikan seks adalah cara-cara berhubungan intim, tapi kenyataannya pendidikan seks adalah pendidikan tentang kesehatan serta fungsional alat kelamin manusia. Seks merupakan bagian dari pendidikan yang harus ditanamkan sejak dini pada anak.

Pendidikan seks atau pendidikan mengenai kesehatan reproduksi (kespro) atau istilah kerennya sex education sudah seharusnya diberikan kepada anak-anak yang sudah beranjak dewasa atau remaja, baik melalui pendidikan formal maupun informal. Ini penting untuk mencegah biasnya pendidikan seks maupun pengetahuan tentang kesehatan reproduksi di kalangan anak anak. Materi pendidikan seks bagi para anak ini terutama ditekankan tentang upaya untuk mengusahakan dan merumuskan perawatan kesehatan seksual dan reproduksi serta menyediakan informasi yang komprehensif termasuk bagi para anak anak. Berikut adalah tahapan pendidikan seks berdasarkan perkembangan anak.

Pada usia 0-2 tahun anak sudah memiliki kemampuan mengenali kelamin dan membedakan antara pria dan wanita dari karakteristik fisik.Pada usia 2-5 tahun anak sudah seharusnya memahami konsep reproduksi paling sederhana bahwa jika seorang pria dan wanita bersama, maka mereka dapat "menciptakan" bayi.Pada usia 6-8 tahun anak sudah sewajarnya memahami bahwa akan terjadi perubahan bada fisik mereka menginjak usia pubertas.Menginjak usia pubertas yaitu usia 9-12 tahun, anak harus mulai memahami konsep hubungan antar lawan jenis yang baik dan tepat. Mereka harus paham tentang konsekuensi dari tindakan mereka.Menginjak usia dewasa yaitu usia 1318 tahun, anak cenderung tertutup perihal perbincangan yang menyangkut seks, namun jika orang tua telah membiasakan pembicaraan ini dari awal, anak akan lebih nyaman dan terbuka (lihat :http://www.vemale.com 14/10/2013).

Seks adalah sebuah masalah. Pernyataan tersebut memiliki makna ganda, tapi memang benar adanya. Sekks memanglah sebuah masalah ketika kita tidak dapat memilih atau menyeleksinya. Seks bukan lah sebuah masalah ketika kita melakukan pembahasan tentang kajian seks.Istilah diatas sangatlah menggambarkan betapa sulit dan rumitnya seks. Akan tetapi seseulit apapun itu, seks dapat disosialisakan sesuai dengan umur dan karakteristik anak itu sendiri. Kita ambil contohketika anak berusia 2-5 tahun, missal seorang anak bertanya kepada ibunya, maka ibu harus mampu menjelaskan arti darseks secara mendalam menggunakan bahasa yang sesuai dengan usia anak tersebut.

Metode konseling pendidikan seks kepada anak dapat dilakukan meliputi 3 aspek, yaitu pertama, Eliminasi Bahasa, Adalah cara menyampaikan informasi dengan 
menggunakan kata kata secukupnya dan tepat sasaran. Dalam hal ini, konselor harus pandai dalam mengubah kata-kata yang kurang senonoh menjadi kata yang mudah didengar dan dipahami oleh klien korban KSA. Ini akan menyebabkan anak lebih mudah menerimanya dan mencernanya dengan pemikiran mereka sendiri. Pertama kita harus mempermudah anak dalam mengerti dan memahami makna dari tiap kata yang berhubungan dengan seks. Tapi yang sering menjadi fatal, konselor pasti ingin menjadi orang intelek yang mengajarkan seks kepada anak dengan takaran dari anak remaja. Hal itu sangatlah tidak dibenarkan, karena hal itu hanya akan menimbulka rasa penasaran dan dapat mengarahkan ke hal yang tak diinginkan.metode ini hanya akan efektif pada anak usia 5-12 tahun karena mereka masih dalam tahap pencarian dan pemahaman. Hal itu bukan merupakan suatu acuan tetap, karena perkembangan pemikiran seorang anak juga dipengaruhi oleh faktor lingkungan dan faktor gaya belajar anak dapat mempercepat pemikiran anak.

Kedua, Toleransi dalam seks, konselor pendidikan seks harus dapat menjadikan seks sebagai sebuah pandangan tentang gaya pendidikan. Yang perlu diubah pertama adalah anggapan dari konselor/pendidik bahwa seks itu memang bagian dari pendidikan wajib bagi anak. Pendidikan merupakan awal dari pendidikan yang akan terjadi, jadi pendidik harus mampu enyampaikan kebenaran tentang seks pada anak didiknya. Toleransi seks juga harus mengajarkan tentang saling menghargai perbedaan antara gender. Dalam hal ini, laki laki juga akan mempelajari sistem seks perempuan dan begitupun sebaliknya. Menurut saya cara ini akan menjadi sangat efektif ketika pengajar mampu menyajikan seks dalam bentuk yang menarik. Mungkin konselor bisa menggunakan alat peraga guna memperjelas gambaran anak tentang alat kelamin lawan jenis mereka. Cara ini dapat mengurangi rasa penasaran dari anak karena mereka sudah mengetahui bagaimana bentuknya. Toleransi seks juga harus mengajarkan tentang perbedaan adat dan kebudayaan dengan keperluan pendidikan. Contoh sederhana adalah dengan menimbulkan anggapan pada anak bahwa pakaian adat daerah papua itu merupakan warisan berharga bagi bangsa ini dan bukan salah satu bentuk dari penyelewengan seks. Ketika anak mampu melakukan toleransi seks tidak menutup kemungkinan kalau dia akan menganggap seks itu sebagai pendidikan wajib dan bukan suatu hal yang tabu.

Ketiga, Penumbuhan pengetahuan tentang seks, ini adalah apa yang kita bahas sejauh ini. Ketika muncul pertanyaan "bagaimana", maka akan timbul jawaban "lakukanlah". Lakukan disini bermakna untuk menyuruh agar mengajarkannya. Konselor harus lebih dulu belajar tentang seks sebelum mengajarkannya. Ketika konselor lebih mendalami materi maka anak akan merasa lebih nyaman dan menjadi yakin akan apa yang disampaikan oleh konselor. Dengan adanya metode ini maka diharapkan jika pendidikan seks menjadi materi wajib yang harus dikuasai oleh setiap konselor. Pendidikan seks menjadi sangat sakral ketika kita menengok kebelakang dan melihat fakta tentang kejahatan seksual di Indonesia. Rendahnya latar belakang pendidikan seks hanya akan mengakibatkan tingginya angka kejahatan seksual. "Ketika 
sesorang mendapat ilmu secara kurang mendalam, secara akan secara alami mencari, menggali, atau mungkin mengembangkan sendiri ilmu itu". Seperti halnya anak-anak yang masih terdapat dalam masa perkembangan. Berkembangnya anak adalah sesuatu yang sangat krusial, perlu dampingan orang dewasa guna mengarahkan kehal yang positif dan bermanfaat bagi apa yang ia perlukan bagi dia kedepannya. Pendidikan seks sangat bermanfaat bagi masa depannya maka dari itu pendidikan seks menjadi sesuatu yang penting bagi anak anak.

Pendidikan seks menjadi sangat penting sekaligus menjadi sesuatu yang sangat berbahaya. Penting karena dapat menghindarkan dari hal hal yang buruk, dan berbahaya karena dapat menjerumuskan pada hal yang negatif seperti seks bebas dan sejenisnya. Kemana arah pendidikan seks sendiri tergantung pada pribadi masing-masing dan peran konselor sebagai pembimbing pada hal-hal positif. Meski pendidikan seks bukan merupakan materi mata pelajaran yang diajarkan langsung di sekolah, tetapi pendidikan seks merupakan dasar dari penyelamatan anak dari pelecehan dan kekerasan seksual.

\section{Konseling Pendidikan Seks dalam Pencegahan Kekerasan Seksual Anak}

Pertambahan usia menyebabkan perubahan hormon dan psikologis anak yang berubah, dimana masa anak-anak ke masa remaja, anak-anak yang berada pada masa peralihan cenderung berupaya untuk mencari jati dirinya, memberontak, dan bertindak semaunya. Psikologis anak juga harus diperhatikan, agar sang anak tidak melakukan tindakan yang salah, peran orang tua sangat penting untuk mendekatkan dengan sang anak, agar sang anak lebih terbuka kepada orang tuanya. Dengan demikian orang tua dapat memberikan nasehat kepada sang anak tentang apa yang boleh dilakukan dan yang dilarang untuk dilakukan. Akan tetapi nasehat hanya akan membuat anak merasa terkekang dan menjadi bersikap lebih tertutup kepada orang tua mereka.

Dalam hal ini peran orang tua sebagai pengarah dan pedoman sangat dibutuhkan untuk mendampingi setiaplangkah anak. Yang terpenting bagi orang tua adalah meinimalisir perkataan yang membuat anak merasa tersudut. "Jadi apakah seks perlu didalami anak menurut psikologi anak?" jawabnya iya, karena anak akan terganggu ketika rasa penasarannya tak terjawab. Dan ketika rasa penasaran tak terjawab, anakakan berusaha mencari tau itu karena rasa ingin tau adalah sifat alami anak. Jadi jangan pernah menutupi arti seks kepada anak karena hanya akan menumbuhkan rasa penasaran di pikiran anak.

Dari analisis di atas, dapat disimpulkan kalau konseling pendidikan seks sangat penting bagi anak dalam segi sosial, psikologi, dan perkembangannya. Pendidikan seks akan menjadi lebih penting ketika kita melihat sisi positif yang akan didapat dengan memperhitungkan sisi negatif yang akan didapat dan sangat disarankan agar semua konselor menguasai dan mampu menyampaikannya pendidikan seks kepada kliennya.Tidak ada jaminan kalau kasus pelecehan seksual pada anak akan berkurang, tapi akan lebih baik jika kita mampu mencegah hal tersebut. Konseling pendidikan seks yang dapat dilakukan, dapat menggunakan lima tahapan konseling yaitu: (1) analisis (2) sintesis 
(3) diagnosis (4) konseling (5) tindakan lanjut.Oleh karena itu pendidikan seks sangat penting bagi anak.

Menurut C. G. Wrenn, konseling adalah relasi pribadi yang dinamik antara dua orang yang berusaha memecahkan masalah dengan mempertimbangkannya bersamasama. (Wrenn, 1951, hlm. 59). Jadi bisa disimpulkan, bahwa konseling seks merupakan proses diskusi yang akan menyelesaikan masalah yang berkaitan dengan seks. Anak usia dini membutuhkan ini karena ini akan berguna bagi perkembangan psikologinya ketika memasuki masa remaja. Ketika anak tidak mendapatkan konseling ini, maka anak akan mengeksplorasinya sendiri dengan cara mereka.

Bisa dibayangkan, anak akan mencari menggunakan media yang sekiranya dapat menyajikan informasi tentang seks. Mengingat kondisi anak yang belum bisa menentukan mana yang baik dan mana yang buruk, anak akan melihat apa yang pertama ia temukan. Bayangkan saja jika anak menemukan sebuah situs yang merupakan situs porno, maka anak akan memperhatikan dan menelaah apa yang ada didalamnya. Kemungkinan terburuk yang akan terjadi adalah anak akan memperaktekan apa yang dia lihat dalam tayangan itu. Anak memang cepat memahami suatu informasi melalui visual lebih cepat daripada melalui audio. Jadi pada dasarnya anak memang harus mendapat bimbingan pendidikan seks yang sesuai dengan umurnya.

Langkah-langkah dalam melakukan konseling pendidikan seks yaitu, (1) Analisis, dalam tahap ini konselor harus menemukan suatu rumusan dari masalah itu dan pengumpulan data tentang KSA. Dalam tahap ini akan diketahui asal usul masalah dan harus dengan cepat menentukan hipotesis dalm masalah tersebut. (2) Sintesis, merupakan langkah merangkum atau mengurutkan data-data dari proses Analisis tadi mengenai masalah KSA. Data yang dirangkum haruslah mempermudah pemahaman dan bukan mempersulit proses. Langkah ini penting karena merupakan langkah awal dari proses konseling itu sendiri. (3) Diagnosis, ini merupakan langkah utama. Dalam langkah ini pembahasan akan lebih menjorok pada permasalahan KSA, sebab-akibat, dan hasil analisa. Dalam langkah ini akan konselor akan mendapatkan metode yang dapat digunakan dalam proses konseling nantinya. Pemilihan metode konseling akan sangat penting mengingat latar belakang psikologis dari tiap orang itu berbeda beda. (4) Konseling, ini adalah proses dimana konselor harus menyampaikan masukan, solusi atau arahan yang telah didapatkan lewat proses sebelumnya. Langkah ini merupakan tindakan nyata yang berupa sosialisasi. Konseling dapat dikatakan sukses apa bila sudah tidak ada pertentangan dalam suatu pemikiran. Pada tahap ini klien korban KSA diharapkan dapat mandiri mengambil keputusannya untuk mengembangkan dan memaksimalkan potensinya (5) Tindak Lanjut, ini hanyalah langkah optional yang akan ditempuh oleh konselor ketika klien belum mengerti mengenai masalah yang dihadapinya dan belum mampu menyelesaikan masalahnya tersebut (Muhammad Surya, 1998).

Sedangkan strategi konselor dalam membantu menyelesaikan masalah klien yang menjadi korban kekerasan seksual. Antara lain dapat dilakukan dengan pendekatan Behaviour, strategi Affect, dan strategi interpersonal relationship. Dimana ketiga strategi 
tersebut dapat digunakan karena ketiganya berhubungan dengan apa yang sedang dirasakan oleh klien yang menjadi korban. Pada strategi Behaviour seorang konselor mengkonseling kliennya dilihat melalui perubahan tingkah laku yang dialami oleh klien yang menjadi korban tersebut seperti halnya klien itu bertingkah laku tidak wajar setelah mengalami kekerasan seksual yang dilakukan oleh pasangannya, korban setelah mengalami kejadian tersebut dia menjadi orang yang pendiam.

Kemudian strategi Affect, yakni strategi dengan melihat perubahan emosi atau perasaan yang dialami oleh klien setelah mengalami kejadian tersebut misalnya dia akan mengalami kecemasan untuk dekat dengan seorang laki-laki setelah mengalami kejadian tersebut. Selanjutnya Strategi interpersonal relationship dimana strategi ini dapat dilakukan melalui perubahan klien dalam melakukan kegiatan pribadinya seperti misalnya dia akan menjadi orang yang takut akan keramaian atau bahkan dia dapat menyendiri dalam ruangan yang tidak ada siapapun hanya dia seorang, karena kejadian tersebut (Lumongga, 2011, hlm. 124).

Setelah strategi ditetapkan tahap konselor selanjutnya adalah memberikan sugesti kepada klien karena sugesti sangat diperlukan perlukan sepanjang proses konseling dilakukan, karena sugesti merupakan senjata yang dibutuhkan oleh konselor untuk meyakinkan klien pada kemampuan yang dimilikinya. Dalam hal ini Corey (2009) mengatakan bahwa jika klien merasakan bahwa konselor memasukan pengharapan kepada dirinya maka klien tersebut akan menaruh harapan itu kepada dirinya sehingga menanamkannya di dalam diri klien tersebut. Pada intinya dari setiap strategi yang seorang konselor juga harus dapat memberikan kenyamanan kepada klien yang ditanganinya, karena dengan adanya kenyamanan yang diberikan seorang klien akan merasa nyaman sehingga tidak sungkan untuk menceritakan hal apa yang di alaminya kepada konselor(Lumongga, 201, hlm. 125). Dengan begitu konselor juga dapat memberikan masukan kepada klien yang sedang di tanganinya tersebut.

Upaya pencegahan kekerasan seksual tidak dapat hanya dilakukan oleh seorang konselor tetapi semua pihak dapat berpartisipasi dalam upaya pencegahan tersebut, termasuk dari jajaran birokrasi pemerintahan. Pencegahan kekerasan terhadap anak yang dapat dilakukan oleh aparat pemerintah meliputi kegiatan: Komunikasi, Informasi dan edukasi tentang pencegahan dan penanganan kekerasan terhadap anak;Penyusunan kebijakan pencegahan kekerasan terhadap anak dan Pelatihan tentang pencegahan dan penanganan kekerasan terhadap anak. Sedangkan strategi pemerintah untuk mengurangi kekerasan seksual pada anak dapat dilakukan dengan cara membuat: Legislasi dan penerapan kebijakan yang melindungi anak dari segala bentuk kekerasan.

Perubahan norma sosial dan praktik budaya yang menerima, membenarkan, atau mengabaikan kekerasan. Pengasuhan yang mendukung hubungan yang aman dan penuh kasih sayang antara pengasuh (khususnya orang tua) kepada anak untuk mencegah kekerasan. Peningkatan keterampilan hidup dan ketahanan diri anak dalam mencegah kekerasan serta mendukung program wajib belajar untuk anak, penyediaan layanan pendukung yang terjangkau dan berkualitas untuk korban kekerasan dan anak pelaku, serta 
anak dalam resiko dan peningkatan kualitas data dan bukti pendukung tentang kekerasan terhadap anak.

Beberap program-program yang dapat dilakukan pemerintah dalam mengurangi kekerasan seksual anak antara lain: Penguatan program bantuan untuk kesejahteraan anak (dana bantuan) dengan menyertakan bantuan pemeriksaan kesehatan anak, prestasi belajar anak, serta pelatihan pengasuhan. Bantuan pinjaman kepada keluarga miskin untuk meningkatkan penghasilan digabungkan dengan pelatihan kesetaraan gender dan pengasuhan. Pelayanan konseling, untuk membantu korban kekerasan dalam membangun kemampuan mengenai kekerasan dan mengubah cara pandang terhadap kekerasan yang dialami.

Kombinasi layanan penilaian (sreening) kasus dengan intervensi rujukan ke layanana terkait. Kelompok yang memberi dukungan emosional dan praktis terhadap anak korban atau anak beresiko dilakukan oleh tenaga professional, pekerja sosial, dan teman sebaya dan Advokasi kasus untuk membantu korban mendapatkan dukungan masyarakat untuk memulihkan atau memperbaiki situasi diri (termasuk penyediaan rumah aman/ singgah, dukungan kelurga asuh, akses kepada pekerjaan, bantuan hukum, pendidikan (Republik Indonesia, Strategi Nasional Penghapusan Kekerasan Seksual terhadap Anak, (Jakarta: 2016, PKTA).

\section{SIMPULAN}

Dalam melakukan konseling pendidikan seks seorang konselor dapat melaksanakan kegiatan konseling dengan menggunakan layanan informasi. Konseling layanan informasi tentu dilakukan dengan secara konseling kelompok. Konseling kelompok merupakan suatu bantuan pada individu dalam situasi kelompo yang bersifat pencegahan dan penyembuhan, serta diarahkan pada pemberian kemudahan dalam dalam perkembangan dan pertumbuhannya.Seorang konselor sebagai fasilitator untuk berjalannya sesi konseling pendidikan seks tersebut. Dengan begitu seorang konselor menjelaskan kepada konseli atau anak apa itu pendidikan seks, kemudian mengenalkan perbedaan lawan jenis, mengenalkan organ seks, menghindari anak dari kemungkinan terjadinya pelecehan seksual, menginformasikan tentang asal-usul anak dan persiapan mengenai pubertas. Dengan begitu pendidikan seks dapat tersampaikan dengan baik dan tepat.

\section{DAFTAR PUSTAKA}

Akbar, Ali. (1982). Seksualitas Ditinjau dari Hukum Islam. Jakarta: Gholia Indonesia.

Basyir, Ahmad Azhar. Ajaran Islam tentang Pendidikan Seks, Hidup Berumah Tangga Pendidikan Anak. Bandung: PT Al Warif.

Darajat, Zakiyah. (1982). Remaja Harapan dan Tantangan. Jakarta: Ruhama. 
80 | Wulandari \& Suteja - Konseling Pendidikan Seks ...

Departemen Agama Republik Indonesia. (2005). Al-Qur'an dan Terjemahnya. Bandung: Jumanatul Ali Art.

El-Quussy, Abdul Aziz. (1984). Pokok-pokok Kesehatan Jiwa/Mental (Jilid I, terjemahan Dr. Zakiyah Daradjat). Jakarta: Bulan Bintang.

Freud, Sighmund. (2003). Teori Seks. Yogyakarta: Jendela.

Gunawan, Ary H. (2010). Sosiologi Pendidikan: Suatu Analisis Sosiologi Tentang Pelbagai Problem Pendidikan. Jakarta: Rineka Cipta.

Hurlock, Elizabeth. (2006). Perkembangan Anak (Jilid II). Jakarta:Media Meitasari Tjandrasa.

Khaliha, M. (2015). Konsepsi Pendidikan Seks untuk Anak dalam Pandangan Abdullah Nashih Ulwan, Epistemé 10 (1).

Madani, Yusuf. (2003). Pendidikan Seks untuk Anaka dalam Islam. Jakarta: Pustaka Zahra.

Madani, Yusuf. (2004). Sex Education 4 Teen (Pendidikan Seks Remaja dalam Islam). Bandung: Mizan.

Miqdad,Akhmad Azhar Abu. (2000). Pendidikan Seks Bagi Remaja menurut Hukum Islam. Yogyakarta: Mitra Pustaka.

Naingggolan, Lukman Hakim. (2008). Bentuk-Bentuk Kekerasan Seksual Terhadap Anak Di Bawah Umur. Jurnal Equality,13 (1).

Qardhowi, Yusuf \& Nasrullah (Terj). (2006). Al-Tarbiyah al-Jinsiyah (Anakku Mari Belajar tentang Seks). Jakarta: Mirqat.

Qibtiyah, Alimatul. (2006). Paradigma Pendidikan Seksualitas (Persfektif Islam Teori dan Praktek). Yogyakarta: Kurnia Kalam Semesta.

Qudsi, Hasan El.(2012). Ketika Anak Bertanya tentang Seks. Solo: Tinta Medina.

Rahmawati, Nanda. (2012). Gambaran Perilaku Seksual Pada Anak Usia Sekolah Kelas 6 Di Tinjau Dari Media Cetak Dan Media Elektronik. Banda Aceh: Jurnal Keperwatan Masyarakat.

Rasyid,Mohamad. (2013). Pendidikan Seks, Mengubah Seks Abnormal Menuju Seks yang Lebih Bermoral. Semarang: Rasail.

Rezkisari,Indira. (2015). KPAI: Pentingnya Pendidikan Seksual Bagi Anak Sejak Usia Dini. Jakarta: diunduh pada 12 Mei 2017 di www.republika.co.id.

Sarwono, Sarlito Wirawan. (2003). Psikologi Remaja. Jakarta: Rajawali Pers. 
Suteja, Jaja. (2008). Pendidikan Seks dalam Perspektif Psikologi Pendidikan Islam. (Tesis). STAIN, Cirebon.

TIM PKBI. (2004). Proses Belajar Aktif Kesehatan Refroduksi Remaja (untuk Anak dan Remaja). Jakarta: PKBI.

Ulwan, Abdullah Nashih \& Hathout, Hassan. (1996). Pendidikan Anak Menurut Islam (Pendidikan Seks). Bandung: PT Remaja Rosdakarya.

Ulwan, Abdullah Nashih. (2015). Pendidikan Anak dalam Islam. Sukoharjo-Jawa Tengah: Al-Andalus.

Widjanarko, Arizal. (1994). Sex Education dalam Pandangan Islam. Jakarta: Palinggan.

Yatimin. (2003). Etika Seksual dan Penyimpangannya dalam Islam. Jakarta: Amzah. 
82 | Wulandari \& Suteja - Konseling Pendidikan Seks ... 